\title{
Formalne aspekty pozasądowego rozwiązywania sporów przed Rzecznikiem Finansowym
}

\section{Wprowadzenie}

Niniejsze opracowanie dotyczy jednej z metod polubownego rozwiązywania sporów konsumenckich, jaką jest pozasądowe rozwiązywanie sporów między klientem a podmiotem rynku finansowego przed Rzecznikiem Finansowym. Spory, które mają charakter cywilnoprawny i mogą być rozwiązywane na drodze sądowej poprzez mediację i postępowanie pojednawcze na podstawie art. $183^{1-15} \mathrm{i}$ art. $184-186$ Kodeksu postępowania cywilnego ${ }^{1}$, zostały poddane regulacji prawa publicznego.

Celem niniejszego opracowania jest analiza uwarunkowań administracyjnoprawnych pozasądowego rozwiązywania sporów przed Rzecznikiem Finansowym, w tym zweryfikowanie, czy proces ten stanowi skuteczny środek ochrony prawnej konsumentów na rynku usług finansowych. Pozasądowe rozwiązywanie sporów przed Rzecznikiem Finansowym w założeniu ma prowadzić do uzyskania szybkich i łatwo dostępnych środków ochrony praw i interesów klientów podmiotów rynku finansowego. Opracowanie ma też na celu ocenę, czy wyżej wymienione założenia są realizowane, a także ocenę tego, czy postępowanie przed podmiotem publicznoprawnym, jakim jest Rzecznik Finansowy, wywiera wpływ na kształt ochrony konsumentów na rynku usług finansowych.

*Marika Piwowarczyk, mgr, Uniwersytet Wrocławski, e-mail: marika.piwowarczyk@ uwr.edu.pl, https://orcid.org/0000-0003-1204-3879.

${ }^{1}$ Ustawa z dnia 17 XI 1964 r. - Kodeks postępowania cywilnego (tekst jedn. Dz.U. 2019, poz. 1460), dalej „k.p.c.”. 
Usługi świadczone przez podmioty rynku finansowego nierzadko wymagają szczególnej ochrony konsumentów. Nie są to typowe usługi, z którymi mamy do czynienia na co dzień. Usługi te mają często skomplikowany charakter. Mimo że klient jest świadomy co do treści głównego świadczenia, to szczegółowe warunki umowy mogą być trudno zrozumiałe dla przeciętnego konsumenta ${ }^{2}$. Klient podmiotu rynku finansowego, zawierając umowę, najczęściej opiera się na wzorcach umownych przedstawianych mu przez podmiot rynku finansowego, kierując się przy tym zaufaniem do tego podmiotu, że składana mu oferta nie narusza jego praw, a także zaufaniem do organów państwa, pozostając w przekonaniu, że jego interesy są i będą odpowiednio chronione ${ }^{3}$.

Ochrona praw konsumentów oraz promowanie ich interesów należą do podstawowych wartości Unii Europejskiej (UE). Zgodnie z art. 12 Traktatu o funkcjonowaniu Unii Europejskiej wymogi ochrony konsumentów są uwzględniane przy określaniu i urzeczywistnianiu innych polityk państw członkowskich, natomiast zgodnie z art. 169 ust. 1 oraz art. 169 ust. 2 lit. a) Unia Europejska ma się przyczyniać do zapewnienia wysokiego poziomu ochrony konsumentów poprzez środki przyjmowane na podstawie art. 114 tego aktu. Ponadto zgodnie z art. 38 Karty Praw Podstawowych Unia Europejska zapewnia wysoki poziom ochrony konsumentów w jej politykach.

Dnia 18 czerwca 2013 r. opublikowany został pakiet legislacyjny UE zawierający Dyrektywę Parlamentu Europejskiego i Rady 2013/11/UE z dnia 21 maja 2013 r. w sprawie alternatywnych metod rozstrzygania sporów konsumenckich oraz zmiany rozporządzenia (WE) nr 2006/2004 i dyrektywy 2009/22/WE ${ }^{4}$, a także Rozporządzenie Parlamentu Europejskiego i Rady (UE) nr 524/2013 z dnia 21 maja 2013 r. w sprawie

${ }^{2}$ Zob. D. Cyman, Zarys systemu instytucjonalnej ochrony praw konsumentów na rynku finansowym, "Gdańskie Studia Prawnicze" 2017, t. 38, s. 325-336, https://www.ceeol. com/search/article-detail?id=606370 (dostęp: 15 IV 2020).

${ }^{3}$ Ibidem.

${ }^{4}$ Dyrektywa Parlamentu Europejskiego i Rady 2013/11/UE z dnia 21 V 2013 r. w sprawie alternatywnych metod rozstrzygania sporów konsumenckich oraz zmiany rozporządzenia (WE) nr 2006/2004 i dyrektywy 2009/22/WE (dyrektywa ADR) (Dz.Urz. UE L 165 z 18 VI 2013, s. 63), dalej "dyrektywa ADR".

ADR (ang. Alternative Dispute Resolution) jest specyficzną konstrukcją teoretyczną, a także dziedziną badań i praktyki. Termin ten odnosi się do procesów rozwiązywania sporów, które są stosowane jako alternatywa dla sporów sądowych, obejmuje polubowne procesy rozwiązywania sporów, takie jak mediacje, arbitraż czy koncyliacje. 
internetowego systemu rozstrzygania sporów konsumenckich oraz zmiany rozporządzenia (WE) nr 2006/2004 i dyrektywy 2009/22/WE5. Pakiet legislacyjny miał na celu „zapewnienie konsumentom możliwości składania wniosków o rozstrzyganie sporów z przedsiębiorcami do podmiotów oferujących niezależne, bezstronne, przejrzyste, skuteczne i szybkie metody ich alternatywnego rozwiązywania"6.

W Polsce implementacja wyżej wymienionego pakietu legislacyjnego na poziomie ustawowym miała miejsce w Ustawie z dnia 23 września 2016 r. o pozasądowym rozwiązywaniu sporów konsumenckich ${ }^{7}$, która w art. 59 wprowadza zmiany w Ustawie z dnia 5 sierpnia 2015 r. o rozpatrywaniu reklamacji przez podmioty rynku finansowego i o Rzeczniku Finansowym ${ }^{8} \mathrm{w}$ zakresie możliwości przeprowadzenia pozasądowego postępowania $\mathrm{w}$ sprawie rozwiązywania sporów między klientem a podmiotem rynku finansowego ${ }^{9}$. Zaznaczyć należy, że pozasądowe

${ }^{5}$ Rozporządzenie Parlamentu Europejskiego i Rady (UE) nr 524/2013 z dnia 21 V 2013 r. w sprawie internetowego systemu rozstrzygania sporów konsumenckich oraz zmiany rozporządzenia (WE) nr 2006/2004 i dyrektywy 2009/22/WE (rozporządzenie ODR) (Dz.Urz. UE L 165 z 18 VI 2013, s. 1), dalej "rozporządzenie ODR”.

Dyrektywa ADR stanowi o tym, że każdy konsument będący w sporze z przedsiębiorcą musi mieć możliwość zwrócenia się o rozwiązanie tego sporu do podmiotu ADR, spełniającego wymagania szczegółowo wskazane w przepisach dyrektywy. Rozporządzenie ODR jest instrumentem pomocniczym w stosunku do dyrektywy. Wymaga ono utworzenia platformy, na której konsumenci będą mogli uzyskać kontakt z podmiotami ADR uregulowanymi przez dyrektywę ADR oraz będą mieli możliwość rozwiązania sporu z przedsiębiorcą przy użyciu formularzy dostępnych na tej platformie, zob. M. Tulibacka, Mediacja w sporach konsumenckich, w: Mediacje. Teoria i praktyka, pod red. E. Gmurzyńskiej, R. Morek, Warszawa 2018.

${ }^{6}$ Uzasadnienie do projektu ustawy o pozasądowym rozwiązywaniu sporów Konsumenckich, s. 1, https://legislacja.rcl.gov.pl/docs//2/12283400/12342474/12342475/ dokument213267.pdf (dostęp: 28 III 2020).

${ }^{7}$ Ustawa z dnia 23 IX 2016 r. o pozasądowym rozwiązywaniu sporów konsumenckich (tekst jedn. Dz.U. 2016, poz. 1823), dalej „ustawa o pozasądowym rozwiązywaniu sporów”.

${ }^{8}$ Ustawa z dnia 5 VIII 2015 r. o rozpatrywaniu reklamacji przez podmioty rynku finansowego i o Rzeczniku Finansowym (tekst jedn. Dz.U. 2019, poz. 2279), dalej „ustawa o rozpatrywaniu reklamacji".

${ }^{9}$ Dnia 21 IX 2020 r. na stronach Rządowego Procesu Legislacyjnego pojawił się Projekt ustawy o rozpatrywaniu reklamacji i sporów klientów podmiotów rynku finansowego oraz o Funduszu Edukacji Finansowej (UD 125), dalej „nowy projekt ustawy o rozpatrywaniu reklamacji i sporów klientów podmiotów rynku finansowego", który przewiduje połączenie w ramach jednego organu zadań w zakresie ochrony interesów konsumentów, tj. likwidację stanowiska Rzecznika Finansowego oraz przeniesienie jego kompetencji na Prezesa Urzędu Ochrony Konkurencji i Konsumentów. Kompetencje Rzecznika Finansowego w zakresie pozasądowego rozpatrywania sporów konsumenckich zgodnie z rozdziałem 4 projektowanej ustawy ma przejąć Koordynator do spraw pozasądowego 
postępowanie w sprawie rozwiązywania sporów między klientem a podmiotem rynku finansowego nie jest konsekwencją implementacji wyżej wymienionego unijnego pakietu legislacyjnego, ale zostało wprowadzone już ustawą o rozpatrywaniu reklamacji.

\section{Pozasądowe rozwiązywanie sporów konsumenckich}

W myśl art. 1-2 dyrektywy ADR jej celem jest osiągnięcie wysokiego poziomu ochrony konsumentów poprzez zapewnienie im możliwości dobrowolnego składania skarg na działania przedsiębiorców do podmiotów oferujących niezależne i bezstronne alternatywne metody rozstrzygania sporów. Dyrektywa ADR ma zastosowanie do postępowań mających na celu pozasądowe rozstrzygnięcie sporów dotyczących zobowiązań umownych wynikających z umów sprzedaży lub umów o świadczenie usług między przedsiębiorcą a konsumentem, poprzez interwencję podmiotu ADR, który proponuje lub narzuca rozwiązanie bądź doprowadza do spotkania stron w celu ułatwienia polubownego rozstrzygnięcia.

Zgodnie z definicjami zawartymi w art. 4 ust 1 dyrektywy ADR przez "konsumenta” należy rozumieć "każdą osobę fizyczną działającą w celach niezwiązanych z jej działalnością handlowa, gospodarcza, rzemieślniczą lub wykonywaniem wolnego zawodu"10, natomiast przez "przedsiębiorcę" należy rozumieć "każdą osobę fizyczną lub prawną, niezależnie od tego, czy jest to podmiot publiczny czy prywatny, która działa - w tym również za pośrednictwem jakiejkolwiek innej osoby działającej w jej imieniu lub na jej rzecz - w celach związanych z jej działalnością handlowa, gospodarcza, rzemieślniczą lub wykonywaniem wolnego zawodu".

Należy zaznaczyć, że zgodnie z motywem 18 dyrektywy ADR definicja "konsumenta" powinna obejmować także przypadki, w których

rozwiązywania sporów między klientem a podmiotem rynku finansowego działający przy Prezesie Urzędu Ochrony Konkurencji i Konsumentów, https://legislacja.rcl.gov. $\mathrm{pl} /$ projekt/12338403/katalog/12719793\#12719793; http://www.sejm.gov.pl/sejm9.nsf/ agent.xsp?symbol=RPL\&Id=RM-10-80-20 (dostęp: 20 XII 2020).

${ }^{10}$ Taką samą definicję zastosowano w art. 2 pkt 1 Dyrektywy Parlamentu Europejskiego i Rady 2011/83/UE z dnia 25 X 2011 r. w sprawie praw konsumentów, zmieniającej dyrektywę Rady 93/13/EWG i dyrektywę 1999/44/WE Parlamentu Europejskiego i Rady oraz uchylającej dyrektywę Rady 85/577/EWG i dyrektywę 97/7/WE Parlamentu Europejskiego i Rady (Dz.Urz. UE L 304 z 22 XI 2011). 
umowa zostaje zawarta w celu tylko częściowo związanym z działalnością gospodarczą danej osoby, który jest na tyle ograniczony, że nie ma charakteru przeważającego w ogólnym kontekście umowy ${ }^{11}$.

W świetle ustawy o pozasądowym rozwiązywaniu sporów konsumenckich, zgodnie z definicjami zawartymi w art. 2 tego aktu, ilekroć w ustawie jest mowa o "konsumencie" $\mathrm{i}$ "przedsiębiorcy" - należy przez to rozumieć konsumenta oraz przedsiębiorcę w rozumieniu Ustawy z dnia 23 kwietnia 1964 r. - Kodeks cywilny, natomiast przez „spór konsumencki" należy rozumieć spór między konsumentem a przedsiębiorcą wynikający z zawartej z konsumentem umowy.

Podmiotem uprawnionym do pozasądowego rozwiązywania sporów konsumenckich zgodnie z art. 4 ust. 1 lit. h) dyrektywy ADR jest każdy podmiot, bez względu na nadaną mu lub używaną w stosunku do niego nazwę, utworzony na stałe i oferujący rozstrzygnięcie sporu w ramach postępowania ADR, umieszczony w wykazie podmiotów ADR prowadzonym przez właściwy organ. Na podstawie ustawy o pozasądowym rozwiązywaniu sporów takim właściwym organem jest Prezes Urzędu Ochrony Konkurencji i Konsumentów, który zgodnie z art. 20 tego aktu prowadzi rejestr podmiotów uprawnionych do pozasądowego rozwiązywania sporów konsumenckich, do którego wpis na podstawie art. 21 ustawy następuje na wniosek.

Stosownie do art. 6 dyrektywy ADR należy zapewnić, by osoby odpowiedzialne za ADR posiadały niezbędną fachową wiedzę i były niezależne oraz bezstronne ${ }^{12}$. W celu zagwarantowania powyższego osoby te powinny być też powoływane na czas gwarantujący niezależność ich działania i mogą zostać zwolnione z ich obowiązków bez wyraźnej przyczyny, a także bez zbędnej zwłoki powinny ujawniać wszelkie okoliczności, które mogą wpłynąć lub być postrzegane jako wpływające na ich niezależność lub bezstronność lub powodować konflikt interesów z jedną ze stron sporu, o którego rozstrzygnięcie są proszone. W konsekwencji wymogów art. 6 dyrektywy ADR na wypadek wystąpienia

${ }^{11}$ Podobną wykładnię pojęcia zastosowano w treści motywu 17 Dyrektywy Parlamentu Europejskiego i Rady 2011/83/UE z 25 X 2011 r. w sprawie praw konsumentów, zmieniającej dyrektywę Rady 93/13/EWG i dyrektywę 1999/44/WE Parlamentu Europejskiego i Rady oraz uchylającej dyrektywę Rady 85/577/EWG i dyrektywę 97/7/ WE Parlamentu Europejskiego i Rady.

${ }^{12}$ Jak stanowi art. 6 dyrektywy ADR, ma to zostać zrealizowane poprzez zapewnienie m.in., by osoby odpowiedzialne za ADR posiadały konieczną wiedzę i umiejętności w dziedzinie alternatywnego lub sądowego rozstrzygania sporów konsumenckich, jak również ogólną znajomość prawa. 
konfliktu interesów konieczne jest zapewnienie ich zastępowalności. Powyższe wymogi zostały odzwierciedlone przez polskiego ustawodawcę wprost w przepisach art. 14- 16 ustawy o pozasądowym rozpatrywaniu sporów.

Jak stanowi motyw 32 dyrektywy ADR, niezależność i uczciwość podmiotów ADR ma podstawowe znaczenie dla wzbudzenia zaufania do mechanizmów ADR i przekonania konsumentów, że gwarantują one sprawiedliwy i niezależny wynik postępowania. Wspomniany wcześniej art. 6 dyrektywy ADR wskazuje warunki, jakie powinna spełniać osoba prowadząca postępowanie ADR, przy czym poza niezależnością oraz bezstronnością wymaga się, aby osoby te posiadały niezbędną wiedzę fachowa, aczkolwiek nie muszą one być prawnikami. Jeżeli jednak procedury ADR prowadzą do wiążącej decyzji, w przypadku kolizji praw art. 11 ust. 1 dyrektywy ADR nakłada na państwo członkowskie obowiązek zapewnienia, aby konsument nie został pozbawiony ochrony przyznawanej mu przez obowiązujące przepisy prawa. Oznacza to, że w każdej procedurze ADR prowadzonej na podstawie dyrektywy, która prowadzi do wiążącej decyzji, jeden lub więcej prawników musi być zaangażowanych w procedurę ADR, ponieważ "ogólna znajomość prawa" nie wystarcza, aby zagwarantować, że obowiązujące prawo nie zostanie pominięte ${ }^{13}$.

\section{Rzecznik Finansowy jako podmiot ADR}

Jak wskazano w poprzednim punkcie, Prezes Urzędu Ochrony Konkurencji i Konsumentów prowadzi rejestr podmiotów uprawnionych do pozasądowego rozwiązywania sporów konsumenckich, do którego wpisu dokonuje się na wniosek, niemniej zgodnie z art. 29 ust. 1 ustawy o pozasądowym rozwiązywaniu sporów nie ma to zastosowania do podmiotów uprawnionych do prowadzenia postępowania w sprawie pozasądowego rozwiązywania sporów konsumenckich na podstawie przepisów odrębnych, takich jak Rzecznik Finansowy. Wpisu tego typu podmiotów do rejestru dokonuje się z urzędu na mocy art. 68 ust. 1 i 2 ustawy o pozasądowym rozwiązywaniu sporów.

${ }^{13}$ M.B.M. Loos, Consumer ADR After Implementation of the ADR Directive: Enforcing European Consumer Rights at the Detriment of European Consumer Law, Centre for the Study of European Contract Law Working Paper, no. 2015-11, s. 9, https://papers.ssrn.com/ sol3/papers.cfm?abstract_id=2685651 (dostęp: 15 IV 2020). 
Rzecznik Finansowy jest podmiotem o charakterze sektorowym, utworzonym w celu rozwiązywania określonych sporów w sektorze finansowym ${ }^{14}$. Jest to instytucja powstała na podstawie ustawy o rozpatrywaniu reklamacji, która zastąpiła funkcjonującą wcześniej instytucję Rzecznika Ubezpieczonych ${ }^{15}$.

$\mathrm{W}$ ustawie o rozpatrywaniu reklamacji uregulowano rozwiązywanie sporów na rynku finansowym z klientami podmiotów rynku finansowego prowadzone przez Rzecznika Finansowego, tj. postępowanie interwencyjne, o które można zwrócić się w przypadku odrzucenia reklamacji przez podmiot rynku finansowego, oraz postępowanie polubowne, o które można złożyć wniosek, jeżeli wyczerpano procedurę reklamacyjną w podmiocie rynku finansowego, będące przedmiotem niniejszej analizy. Rzecznik Finansowy jest członkiem sieci rozstrzygania sporów finansowych FIN-NET, w skład której wchodzi także Sąd Polubowny przy Komisji Nadzoru Finansowego, zajmujący się sporami między konsumentami i instytucjami finansowymi, a także Arbiter Bankowy przy Związku Banków Polskich, rozstrzygający spory dotyczące roszczeń z zakresu niewykonania lub nienależytego wykonania czynności bankowych ${ }^{16}$.

Ustawa o rozpatrywaniu reklamacji w art. 13 wskazuje warunki, które musi spełniać osoba powołana na stanowisko Rzecznika Finansowego, m.in.: wyróżniać się wiedzą w zakresie funkcjonowania rynku finansowego i regulacji prawnych w tym zakresie oraz posiadać co najmniej siedmioletnie doświadczenie zawodowe w tym obszarze, posiadać wyższe wykształcenie, korzystać z pełni praw publicznych, posiadać obywatelstwo polskie, być nieskazanym prawomocnym wyrokiem za przestępstwo umyślne.

Zgodnie z art. 19 ustawy o rozpatrywaniu reklamacji Rzecznik Finansowy wykonuje swoje zadania przy pomocy nie więcej niż trzech zastępców, przy czym zastępcą może być osoba spełniająca wymogi właściwe dla Rzecznika Finansowego, z tym wyjątkiem, że powinna posiadać co najmniej pięcioletnie doświadczenie zawodowe w obszarze

${ }^{14}$ M. Tulibacka, Mediacja..., s. 324.

${ }^{15}$ J. Rzeszowski, Rzecznik Finansowy - "nowa-stara” ochrona konsumenta?, "Zeszyt Studencki Kół Naukowych Wydziału Prawa i Administracji UAM" 2017, nr 7, s. 191, https:// repozytorium.amu.edu.pl/handle/10593/18810 (dostęp: 15 IV 2020).

${ }^{16}$ P. Liwoch, Rzecznik Finansowy - analiza działalności w zakresie alternatywnych metod rozstrzygania sporów, „Finanse i Prawo Finansowe” 2018, t. 4(20), s. 18, http://dspace.uni. lodz.pl/xmlui/handle/11089/26403 (dostęp: 15 IV 2020). 
funkcjonowania rynku finansowego. Ponadto stosownie do art. 18 ustawy o rozpatrywaniu reklamacji Rzecznik Finansowy wykonuje swoje zadania przy pomocy podległego mu Biura Rzecznika, w skład którego wchodzi Wydział Pozasądowego Rozwiązywania Sporów ${ }^{17}$.

Ustawa o rozpatrywaniu reklamacji nie wskazuje wprost, że Rzecznik Finansowy jest podmiotem niezależnym, ale wprowadza w art. 23 zasady mające zapewniać niezależność i bezstronność. Stosownie do tego przepisu Rzecznik Finansowy nie może zajmować innego stanowiska, z wyjątkiem stanowiska badawczo-dydaktycznego lub badawczego oraz naukowo-dydaktycznego lub naukowego, ani wykonywać innych zajęć zawodowych, należeć do partii politycznej, być akcjonariuszem, udziałowcem, członkiem władz ani wykonywać obowiązków członka zarządu lub rady nadzorczej podmiotów rynku finansowego ani wykonywać czynności związanych z działalnością w zakresie świadczenia usług przez te podmioty, nie może też wykonywać innych czynności, które pozostają w sprzeczności z jego obowiązkami albo mogą wywołać podejrzenie o jego stronniczość lub interesowność, czy też prowadzić działalności publicznej niedającej się pogodzić z obowiązkami i godnością jego urzędu.

Przytoczone wyżej warunki pełnienia funkcji Rzecznika Finansowego korespondują z warunkami wskazanymi w art. 6 dyrektywy ADR. Pamiętać jednak należy, że Rzecznik Finansowy jako podmiot uprawniony w zakresie pozasądowego rozwiązywania sporów konsumenckich realizuje swoje zadania w tym zakresie poprzez osoby zatrudnione w Biurze Rzecznika i to również do nich, jako osób prowadzących postępowanie w sprawie pozasądowego rozwiązywania sporów konsumenckich, odnoszą się warunki niezależności i bezstronności.

Wymogi co do osoby prowadzącej pozasądowe postępowanie w sprawie rozwiązywania sporów między klientem a podmiotem rynku finansowego wskazuje art. 35b ustawy o rozpatrywaniu reklamacji. Stosownie do postanowień tego artykułu tego typu postępowanie może być prowadzone przez osobę upoważnioną przez Rzecznika Finansowego, przy czym upoważnienie udzielane jest na czas określony. Upoważnienie może być udzielone osobie wyróżniającej się wiedzą w zakresie funkcjonowania rynku finansowego i regulacji prawnych w tym zakresie, posiadającej co najmniej pięcioletni staż pracy, w tym

17 Zarządzenie nr 127 Prezesa Rady Ministrów z dnia 26 X 2015 r. w sprawie nadania statutu Biura Rzecznika Finansowego (M.P. 2015, poz. 1055). 
co najmniej trzyletnie doświadczenie zawodowe w tym obszarze. Osoba upoważniona powinna prowadzić postępowanie w sposób niezależny i bezstronny. Udzielone upoważnienie może zostać cofnięte przed upływem okresu, na jaki zostało udzielone, w określonych w ustawie przypadkach, $\mathrm{tj}$. w przypadku: rażącego naruszenia prawa przy wykonywaniu funkcji, skazania prawomocnym wyrokiem za popełnione umyślnie przestępstwo lub przestępstwo skarbowe, choroby trwale uniemożliwiającej wykonywanie zadań.

Szczegółowe wymogi w tym zakresie określone są w rozporządzeniu wykonawczym do art. 43 ustawy o rozpatrywaniu reklamacji, tj. w Rozporządzeniu Ministra Rozwoju i Finansów z dnia 15 lutego 2017 r. W sprawie pozasądowego postępowania przed Rzecznikiem Finansowym ${ }^{18}$. Zgodnie z $\$ \S 2-3$ tego rozporządzenia osoba prowadząca postępowanie powinna posiadać: wyższe wykształcenie prawnicze lub ekonomiczne oraz wiedzę w zakresie sądowego lub pozasądowego rozwiązywania sporów, a także wyróżniać się wiedzą w zakresie umów zawieranych pomiędzy klientem a podmiotem rynku finansowego. Upoważnienia do prowadzenia postępowania udziela się na czas określony, nie krótszy niż 6 miesięcy i nie dłuższy niż 3 lata, przy czym osoba upoważniona bierze udział w rozpoznaniu sprawy rozpoczętej z jej udziałem do czasu jej zakończenia mimo upływu okresu, na który zostało udzielone upoważnienie. Upoważnienie może być udzielone ponownie tej samej osobie.

Należy zauważyć, że zarówno ustawa o rozpatrywaniu reklamacji, jak i rozporządzenie w sprawie pozasądowego postępowania przed Rzecznikiem Finansowym nie reguluja, jak postępować w przypadku wystąpienia okoliczności, które mogą wpłynąć na niezależność lub bezstronność osób prowadzących postępowanie lub powodować konflikt interesów z jedną ze stron sporu. Zastosowanie w tym zakresie znajduje art. 16 ustawy o pozasądowym rozwiązywaniu sporów w zw. z art. 35a ustawy o rozpatrywaniu reklamacji.

Zgodnie z art. 16 ustawy o pozasądowym rozwiązywaniu sporów osoba prowadząca postępowanie ma obowiązek niezwłocznego ujawnienia podmiotowi uprawnionemu, w tym przypadku Rzecznikowi Finansowemu, okoliczności, które mogą wpłynąć na jej niezależność lub bezstronność lub powodować konflikt interesów z jedną ze stron

${ }_{18}$ Tekst jedn. Dz.U. 2017, poz. 313, dalej „Rozporządzenie w sprawie pozasądowego postępowania przed Rzecznikiem Finansowym". 
sporu. W takiej sytuacji Rzecznik Finansowy jako podmiot uprawniony w rozumieniu ustawy o pozasądowym rozwiązywaniu sporów może przekazać prowadzenie postępowania innej osobie, a jeżeli nie jest to możliwe, to wyłącza osobę dotychczas prowadzącą postępowanie $\mathrm{z}$ dalszego toku postępowania oraz proponuje stronom postępowania przekazanie sporu innemu podmiotowi uprawnionemu.

W przypadku gdy zaproponowanie przekazania sporu innemu podmiotowi uprawnionemu nie jest możliwe, należy ujawnić stronom postępowania okoliczności wyłączające niezależność lub bezstronność osoby prowadzącej postępowanie lub powodujące konflikt interesów oraz poinformować strony postępowania o prawie zgłoszenia sprzeciwu wobec dalszego prowadzenia danego postępowania przez osobę, której dotyczą te okoliczności. Jeżeli strony nie zgłoszą sprzeciwu, to osoba, której dotyczą wskazane okoliczności, może dalej prowadzić postępowanie. Ustawa o pozasądowym rozwiązywaniu sporów konsumenckich nie reguluje, co dzieje się w przypadku zgłoszenia sprzeciwu, niemniej postępowanie nie może być dalej prowadzone przez podmiot uprawniony, a zatem strony muszą skorzystać z innej formy rozwiązania sporu niż pozasądowe rozwiązywanie sporu przed Rzecznikiem Finansowym.

\section{Alternatywne rozwiązywanie sporu przed Rzecznikiem Finansowym}

Ustawa o rozpatrywaniu reklamacji wprowadza w rozdziale IV pozasądowe postępowanie w sprawie rozwiązywania sporów między klientem a podmiotem rynku finansowego, przy czym pojęcia te odnoszą się do osoby fizycznej będącej klientem podmiotu z sektora ubezpieczeniowego, emerytalnego i bankowo-kapitałowego, która działa w celach niezwiązanych z jej profesjonalną działalnością ${ }^{19}$. Pojęcia te zawierają się $\mathrm{w}$ definicji konsumenta i przedsiębiorcy, o których mowa w art. 4 ust. 1 dyrektywy ADR.

Należy zaznaczyć, że korzystanie z usług finansowych może być dla przeciętnego, nieprofesjonalnego klienta związane nie tylko z brakiem ich transparentności, ale też $\mathrm{z}$ brakiem wiedzy w zakresie przepisów w sferze usług finansowych, w tym w zakresie przysługujących

${ }^{19}$ Por. art. 2 pkt 1 oraz 3 ustawy z dnia 5 VIII 2015 r. o rozpatrywaniu reklamacji przez podmioty rynku finansowego i o Rzeczniku Finansowym. 
mu praw ${ }^{20}$. Konieczne jest zatem przekazanie klientowi, który korzysta $z$ usług finansowych, odpowiedniej informacji zarówno na etapie przedkontraktowym, jak i w trakcie nawiązanej relacji z przedsiębiorca, co ma na celu nie tylko dostarczenie klientom wiedzy i świadomości w zakresie warunków umowy i przysługujących im praw, ale też przede wszystkich zapewnienie im ochrony ${ }^{21}$.

Ustawodawca $w$ ustawie o rozpatrywaniu reklamacji nakłada na podmiot rynku finansowego obowiązki informacyjne związane z procesem rozpatrywania reklamacji, które ten musi spełnić wobec klienta. Zgodnie z art. 4 ustawy o rozpatrywaniu reklamacji podmiot rynku finansowego powinien zamieścić $w$ umowie zawieranej z klientem szczegółowe informacje dotyczące procedury składania i rozpatrywania reklamacji. Następnie, stosownie do art. 10 tego aktu, w przypadku nieuwzględnienia przez podmiot rynku finansowego roszczeń klienta wynikających z reklamacji podmiot rynku finansowego w odpowiedzi powinien zawrzeć pouczenie o możliwości skorzystania ze środków odwoławczych, w tym przed organami ochrony prawa, co obejmuje także możliwości skorzystania z instytucji mediacji albo sądu polubownego, albo innego mechanizmu polubownego rozwiązywania sporów, oraz o możliwości wystąpienia z wnioskiem o rozpatrzenie sprawy do Rzecznika Finansowego ${ }^{22}$.

Stosownie do postanowień rozdziału IV ustawy o rozpatrywaniu reklamacji postępowanie polubowne przed Rzecznikiem Finansowym jest wszczynane na wniosek klienta podmiotu rynku finansowego. Klient podmiotu rynku finansowego może wnioskować o rozstrzygnięcie sporu przez wykorzystanie jednej z dwóch metod: mediacji, tj. umożliwienia zbliżenia stanowisk stron w celu rozwiązania sporu, lub koncyliacji, tj. przedstawienia stronom propozycji rozwiązania sporu ${ }^{23}$.

${ }^{20}$ Zob. M. Dziedzic, Rola obowiązków informacyjnych przedsiębiorcy wobec konsumenta $w$ sferze ustug finansowych, w: Ochrona konsumenta na polskim i międzynarodowym rynku finansowym, pod red. J. Monkiewicz, E. Rutkowskiej-Tomaszewskiej, Warszawa 2019, s. $86-100$.

${ }^{21}$ Ibidem.

${ }^{22}$ Przytoczone wyżej obowiązki nałożone na przedsiębiorcę odpowiadają art. 13 dyrektywy ADR, zgodnie z którym państwa członkowskie Unii powinny zapewnić, aby przedsiębiorcy mający siedziby na ich terytorium informowali konsumentów o podmiotach ADR właściwych dla danych przedsiębiorców, w przypadkach gdy zobowiązują się oni lub są zobowiązani do korzystania z tych podmiotów w celu rozstrzygania sporów z konsumentami.

${ }^{23}$ P. Liwoch, Rzecznik Finansowy..., s. 18. 
Wniosek o wszczęcie postępowania przez Rzecznika Finansowego, zgodnie z $\$ 6$ Rozporządzenia w sprawie pozasądowego postępowania przed Rzecznikiem Finansowym, poza oznaczeniem stron powinien zawierać m.in.: określone żądanie, określenie oczekiwania co do sposobu zakończenia sporu, opis stanu faktycznego sprawy oraz wskazanie rodzaju postępowania ${ }^{24}$. Zgodnie $\mathrm{z}$ tym przepisem do wniosku należy dołączyć informacje na temat dotychczasowego przebiegu sporu oraz kopie dokumentów potwierdzających informacje wskazywane we wniosku, w stosownych przypadkach wskazać okoliczności, które uniemożliwiają ich dołączenie. Za złożenie wniosku zgodnie $\mathrm{z}$ art. 38 ustawy o rozpatrywaniu reklamacji należy uiścić opłatę w wysokości 50 zł, przy czym klient rynku finansowego może zostać zwolniony z opłaty ze względu na szczególne okoliczności.

Stosownie do $\S 6$ ust. 3 Rozporządzenia w sprawie pozasądowego postępowania przed Rzecznikiem Finansowym klient podmiotu rynku finansowego do wniosku dołącza też informację, czy Rzecznik Finansowy podejmuje lub podejmował działania interwencyjne ${ }^{25}$, reprezentując jego interesy, a także czy sprawa o to samo roszczenie między tymi samymi stronami jest $\mathrm{w}$ toku albo została już rozpatrzona przez Rzecznika Finansowego w postępowaniu polubownym, sąd polubowny, inny właściwy podmiot albo sąd. Postępowanie wszczyna się z chwilą wpływu wniosku zawierającego co najmniej oznaczenie klienta i podmiotu rynku finansowego, dokładne określenie żądania, określenie, czy klient wnosi o mediację czy koncyliację.

Zgodnie z art. 37 ustawy o rozpatrywaniu reklamacji udział podmiotu rynku finansowego w polubownym postępowaniu przed Rzecznikiem Finansowym jest obowiązkowy w przeciwieństwie do postępowania przed innymi podmiotami ADR właściwymi dla sektora finansowego ${ }^{26}$.

\footnotetext{
${ }^{24}$ Por. art. 36 ustawy o rozpatrywaniu reklamacji i art. 33 ustawy o pozasądowym rozpatrywaniu sporów.

${ }^{25}$ Artykuł 17 ust. 1 pkt 1 i 2 ustawy o rozpatrywaniu reklamacji.

${ }^{26}$ Wymóg ten dopuszcza motyw 49 dyrektywy ADR, zgodnie z którym „dyrektywa nie powinna wymagać, aby udział przedsiębiorców w postępowaniach ADR był obowiązkowy ani by wynik takich postępowań był wiążący dla przedsiębiorców, gdy konsument wniósł przeciwko nim skargę. Aby jednak zapewnić konsumentom możliwość dochodzenia roszczeń oraz aby nie musieli oni rezygnować ze swoich roszczeń, przedsiębiorców należy zachęcać, by w miarę możliwości uczestniczyli w postępowaniach ADR. Niniejsza dyrektywa powinna zatem pozostawać bez uszczerbku dla wszelkich przepisów krajowych przewidujących obowiązek udziału przedsiębiorców w takich postępowaniach, przewidujących zachęty lub kary z tym związane".
} 
Rzecznik Finansowy może odmówić wszczęcia postępowania w przypadku, gdy: przedmiot wniosku wykracza poza kategorie sporów objęte właściwością Rzecznika Finansowego, klient nie wyczerpał drogi postępowania reklamacyjnego w sporze $\mathrm{z}$ podmiotem rynku finansowego, wniosek o wszczęcie postępowania spowoduje uciążliwości dla podmiotu rynku finansowego, sprawa jest w toku albo została już rozpatrzona przez Rzecznika Finansowego w postępowaniu polubownym lub została rozpatrzona przez sąd polubowny lub inny właściwy podmiot albo sąd, rozpatrzenie sporu spowodowałoby poważne zakłócenie działania Rzecznika Finansowego oraz gdy klient nie uiścił należnej opłaty od wniosku ${ }^{27}$. W drodze praktyki wypracowana została również instytucja pozostawienia wniosku bez rozpoznania, chociaż nie została ona przewidziana przez ustawodawcę ${ }^{28}$. Stosuje się ją w sytuacji, gdy wniosek klienta nie zawierał obligatoryjnych elementów wniosków, jak oznaczenie stron czy określenie żądania bądź podpis ${ }^{29}$.

$\mathrm{W}$ toku postępowania podmiot rynku finansowego jest zapoznawany z roszczeniem klienta, Rzecznik Finansowy przedstawia stronom postępowania przepisy prawa mające zastosowanie w danej sprawie, a także podejmuje w zależności od rodzaju postępowania działania mediacyjne lub koncyliacyjne. Jeżeli zajdzie taka potrzeba i przemawia za tym charakter sporu, Rzecznik Finansowy może wyznaczyć posiedzenie, na które wzywa stronę lub strony postępowania w celu przedstawienia ich stanowiska i propozycji ${ }^{30}$.

Postępowanie polubowne przy Rzeczniku Finansowym prowadzone jest w postaci pisemnej lub za pośrednictwem środków komunikacji elektronicznej. Rzecznik Finansowy informuje strony postępowania polubownego o podejmowanych czynnościach pisemnie, natomiast jeżeli to możliwe i przemawiaja za tym okoliczności sprawy - za pomocą środków komunikacji elektronicznej ${ }^{31}$. Również sam wniosek o wszczęcie postępowania może być przesłany przesyłką pocztową albo za pomocą środków komunikacji elektronicznej. Powyższe elementy sprawiają, że dla przeciętnego konsumenta postępowanie przed Rzecznikiem Finansowym jest łatwiej dostępne niż postępowanie sądowe.

${ }^{27}$ Por. art. 5 ust. 4 dyrektywy ADR.

${ }^{28}$ P. Liwoch, Rzecznik Finansowy..., s. 19.

${ }^{29}$ Ibidem.

${ }^{30}$ Zob. § 13 rozporządzenia w sprawie pozasądowego postępowania przed Rzecznikiem Finansowym.

${ }^{31}$ Ibidem. 
Postępowanie polubowne przed Rzecznikiem Finansowym może zostać zakończone $\mathrm{w}$ formie ugody, a gdy strony nie dojdą do porozumienia, zgodnie z art. 40 ustawy o rozpatrywaniu reklamacji Rzecznik Finansowy sporządza opinię, w której zawarta jest ocena prawna stanu faktycznego przedmiotowego postępowania. Postępowanie może także zostać umorzone - w przypadku gdy klient wycofa wniosek albo gdy prowadzenie postępowania jest $\mathrm{z}$ innych przyczyn niemożliwe ${ }^{32}$.

Z każdego postępowania polubownego sporządzany jest protokół, w którym należy zawrzeć informacje dotyczące miejsca i czasu oraz stron postępowania, przedmiotu sporu, a ponadto informację o sposobie zakończenia sporu ${ }^{33}$. Protokół ten ${ }^{34}$ stanowi dokument urzędowy $\mathrm{w}$ rozumieniu art. 244 k.p.c.

\section{Dane statystyczne}

Zgodnie z informacjami zawartymi w sprawozdaniu z działalności Rzecznika Finansowego za 2019 r. ${ }^{35}$ do Rzecznika Finansowego wpłynęły łącznie 2732 wnioski o rozwiązanie sporu klienta podmiotu rynku finansowego. W stosunku do 2018 r. nastąpił spadek liczby wpływających wniosków ${ }^{36}$, nadal jednak powadzono sprawy zainicjowane wnioskami z poprzednich lat, w których liczba wpływających wniosków była wyższa ${ }^{37}$.

${ }^{32}$ P. Liwoch, Rzecznik Finansowy..., s. 19.

${ }^{33}$ Por. M. Tabernacka, Sporządzanie dokumentów podczas negocjacji i mediacji w sferze publicznej, w: eadem, Negocjacje i mediacje w sferze publicznej, Warszawa 2018.

${ }^{34}$ Artykuł 41 ust. 2 ustawy o rozpatrywaniu reklamacji.

${ }^{35}$ Sprawozdanie z działalności Rzecznika Finansowego w 2019 r. oraz uwagi o stanie przestrzegania prawa i interesów klientów podmiotów rynku finansowego i Sprawozdanie z działalności w 2019 r. finansowanej ze środków funduszu edukacji finansowej wraz z informacją o wykorzystaniu środków funduszu, https://rf.gov.pl/wp-content/ uploads/2020/05/2019_Sprawozdanie_Rzecznika_Finansowego.pdf (dostęp: 30 III 2021).

${ }^{36}$ Liczba wniosków zmniejszyła się z 4014 w roku 2018 do 2732 w roku 2019, tj. o 32\%.

37 Zdaniem Rzecznika Finansowego wyrażonym w sprawozdaniu z działalności Rzecznika Finansowego w 2019 r. spadek liczby wniosków spowodowany jest zachowaniem posiadaczy kredytów hipotecznych w CHF, którzy stanowią znaczną część wnioskodawców. Według Rzecznika Finansowego w latach 2017-2018 osoby te były zainteresowane zabezpieczeniem swojej sytuacji prawnej, dzięki możliwemu przerwania biegu przedawnienia roszczeń na mocy art. 36 ustawy o pozasądowym rozwiązywaniu sporów konsumenckich. Z wejściem w życie tej ustawy zbiegł się moment, kiedy przedawnieniu mogłyby ulegać roszczenia osób, które zaciągnęły kredyty w $\mathrm{CHF}$ w latach 2006-2008. Ponadto spadek zainteresowania pozasądowym rozwiązaniem sporu przez 
Rzecznik Finansowy w 2019 r. wszczął łącznie 2309 postępowań, w tym 265 to sprawy z wniosków złożonych w 2018 r. i 2044 sprawy z wniosków zarejestrowanych w 2019 r., co stanowi ponad 84\% wszystkich wniosków. Pozostałe 16\% spraw to wnioski pozostawione bez rozpoznania lub w których odmówiono wszczęcia postępowania oraz sprawy przekazane do innego właściwego wydziału, a także wnioski, które na koniec roku sprawozdawczego znajdowały się na etapie wstępnej analizy pod kątem formalnym.

Pozostawienie wniosków bez rozpoznania może być powiązane z faktem, że w 2019 r. klienci podmiotów rynku finansowego tylko w 33\% wniosków o postępowanie polubowne występowali za pomoca pełnomocnika, co mogło prowadzić np. do braków formalnych. Zgodnie z zasadami dyrektywy ADR podmioty ADR powinny zapewnić, aby postępowanie polubowne było łatwo dostępne, a jego zasady przejrzyste, co powinno mieć odzwierciedlenie również w zakresie spełniania formalnych wymogów dla składanych wniosków ${ }^{38}$.

$\mathrm{W}$ zakresie merytorycznego zakończenia postępowania, tj. zawarcia porozumienia, albo w przypadku jego braku wydanie opinii przez Rzecznika Finansowego w 2019 r. zakończono z tytułu powołanych wyżej przesłanek w 2997 sprawach, przy czym w tej liczbie zawieraja się sprawy z lat poprzednich. 1837 spraw zostało zakończonych opinią, co stanowi $61 \%$ wszystkich zakończonych spraw. W 369 sprawach między stronami doszło do zawarcia porozumienia, co stanowi $12 \%$ wszystkich spraw zakończonych w 2019 r. Pozostałe zakończone sprawy to sprawy pozostawione bez rozpoznania, z odmową rozpatrzenia sporu lub umorzone.

Średni okres trwania postępowań w roku 2019 to 375 dni i jest on zbliżony do roku poprzedniego. Liczba wniosków i ich różnorodność pod względem produktowym oraz oczekiwań stron co do sposobu zakończenia postępowań ma największy wpływ na średnią długość trwania postępowania, zwłaszcza w przypadku spraw z sektora rynku bankowo-kapitałowego, które cechuje nie tylko złożoność zagadnień

wskazaną grupę osób w 2019 r. wynikał ze zmian w orzecznictwie sądowym dotyczącym kredytów hipotecznych w CHF wywołanych wyrokiem TSUE z dnia 3 X 2019 r. w sprawie C-260/18 (Dziubak v. Raiffeisen Bank International AG Oddział w Polsce). Klienci banków zaczęli być mniej zainteresowani ugodowym rozwiązaniem sporu na rzecz orzeczenia nieważności zawartych umów, zob. Sprawozdanie z działalności Rzecznika Finansowego w 2019 r., s. 43-44.

${ }^{38}$ Por. art. 5 i 7 dyrektywy ADR. 
prawnych, ale znaczna polaryzacja stanowisk stron. W większości tego typu przypadków postępowanie nie jest zakończone porozumieniem, ale opinią Rzecznika Finansowego.

\section{Znaczenie pozasądowego rozwiązywania sporów przed Rzecznikiem Finansowym}

Pozasądowe rozwiązywanie sporów przed Rzecznikiem Finansowym jest jedną z metod alternatywnego rozwiązywania sporów konsumenckich, która wprowadziła zmiany w istniejącej rzeczywistości wymiaru sprawiedliwości w sprawach cywilnych, tworząc dodatkową ścieżkę dla konsumentów ${ }^{39}$, a właściwie dla klientów pomiotów rynku finansowego w celu uzyskania stosunkowo szybkich i łatwo dostępnych środków ochrony ich praw.

Obowiązkowy udział podmiotu rynku finansowego w postępowaniu skutkuje tym, że przed Rzecznikiem Finansowym toczą się postępowania, które przed innym podmiotem ADR mogłyby nigdy nie mieć miejsca ze względu na brak zgody obu stron na jego przeprowadzenie, stąd duża liczba wniosków i toczących się postępowań, które mimo trwania średnio około roku i tak są krótsze niż kilkuletnie postępowania sądowe $^{40}$. Powyższe wydaje się sprzeczne z ideą polubownego rozwiązywania sporów, jeżeli udział w postępowaniu jednej ze stron nie jest dobrowolny, a przystąpienie do niego podmiotu rynku finansowego następuje niejako $\mathrm{z}$ przymusu. $\mathrm{W}$ obronie wymogu ustanowionego przez ustawodawcę podkreśla się, że mimo iż udział przedsiębiorcy w postępowaniu jest obowiązkowy, to Rzecznik Finansowy nie posiada instrumentów wymuszających na stronach postępowania określone rozstrzygnięcie sporu, a przedstawia jedynie propozycje jego zakończenia ${ }^{41}$.

Niemniej postępowanie polubowne przed Rzecznikiem Finansowym nie zawsze przyniesienie wymierną korzyść konsumentowi, nie tylko ze względu na możliwość zakończenia poprzez wydanie jedynie opinii prawnej, ale i ze względu na to, że jeżeli dojdzie do zawarcia

\footnotetext{
${ }^{39}$ Mowa o dodatkowej ścieżce, poza możliwością mediacji i postępowaniem pojednawczym, na podstawie art. $183^{1-15} \mathrm{i}$ art. $184-186$ k.p.c.

${ }^{40}$ Sprawozdanie z działalności Rzecznika Finansowego w 2019 r., s. 47.

${ }^{41}$ A. Bogusławski, Pozasądowe rozwiązywanie sporów z podmiotem rynku finansowego jako element ochrony konsumenta, „Finanse i Prawo Finansowe” 2016, III(1), s. 33, http://yadda. icm.edu.pl/yadda/element/bwmeta1.element.hdl_11089_17857 (dostęp: 15 IV 2020).
} 
porozumienia, to może być ono mniej korzystne dla klienta podmiotu rynku finansowego niż postępowanie sądowe ${ }^{42}$. Dlatego też, zgodnie z wnioskami Rzecznika Finansowego zawartymi w sprawozdaniu z jego działalności w 2019 r., klient podmiotu rynku finansowego raczej nie będzie zainteresowany ugodowym rozwiązaniem sporu, jeżeli na drodze postępowania sądowego ma szansę zawalczyć o pełne uwzględnienie swojego roszczenia.

Wątpliwości może jednak budzić efektywność tego postępowania, również w kontekście opinii samego Rzecznika Finansowego zawartej w sprawozdaniu z jego działalności za 2019 r. w zakresie zakończenia postępowania $\mathrm{w}$ wariancie, o którym mowa $\mathrm{w}$ art. 40 ustawy o rozpatrywaniu reklamacji, tj. opinią prawną.

Jak podkreśla sam Rzecznik Finansowy w sprawozdaniu ze swojej działalności za rok 2019, opinia jest nietypowym elementem postępowania polubownego, którego charakter powinien opierać się na negocjacjach i doprowadzaniu do osiągnięcia porozumienia, a nie na dokonaniu oceny prawnej sporu. Rzecznik Finansowy twierdzi dalej, że „opinia ma charakter dodatkowy i jej sporządzenie nie zawsze leży w interesie stron, dla których priorytetem jest jednak doprowadzenie do zakończenia sporu. Wymóg sporządzenia opinii prowadzi do istotnego obciążenia osób prowadzących postępowanie, a tym samym opóźnia podjęcie działań mediacyjnych w innych sprawach. W ocenie Rzecznika, obowiązek sporządzenia opinii w trakcie trwania postępowania «sztucznie» wydłuża czas jego trwania. W zdecydowanej większości spraw czynności mediacyjne zostają zakończone w stosunkowo krótkim okresie czasu, niemniej, konieczność sporządzenia opinii w ramach trwającego postępowania, znacznie je wydłuża. $Z$ tego względu zasadnym jest postulat zmiany przepisów proceduralnych w taki sposób, aby postępowanie było kończone po zakończeniu działań mediacyjno-koncyliacyjnych, a opinia była sporządzana po jego zakończeniu, na wniosek strony"43.

Z jednej strony nie sposób nie zgodzić się z powyższym w zakresie istoty postępowania polubownego, które powinno prowadzić do zawarcia porozumienia. $Z$ drugiej jednak strony postępowanie polubowne przed Rzecznikiem Finansowym jest jednym ze środków ochrony prawnej. Zakończenie postępowania opinią prawną może być ważne

${ }^{42}$ Zob. C. Cauffman, Critical Remarks on the ARD Directive, Maastricht European Private Law Institute Working Paper, no. 2016/13, https://papers.ssrn.com/sol3/papers. cfm?abstract_id=2885509 (dostęp: 15 IV 2020).

${ }^{43}$ Sprawozdanie z działalności Rzecznika Finansowego w 2019 r., s. 54. 
dla klienta rynku finansowego jako słabszej strony sporu, która sama nie posiada fachowej wiedzy w zakresie przedmiotu sporu. Opinia może stanowić pomocny materiał, jeśli dojdzie do dalszego postępowania na drodze sądowej.

Stanowisko Rzecznika Finansowego wyrażone w sprawozdaniu z jego działalności za 2019 r. może zarówno świadczyć o tym, że podmiot ten nie radzi sobie z liczbą procesowanych wniosków o pozasądowe rozwiązanie sporu, jak i budzić wątpliwości co do tego, czy osoby uprawnione do prowadzenia postępowania zapewniają jego odpowiednią obsługę merytoryczną. Chociaż osobą upoważnioną do prowadzenia postępowania może być tylko osoba wyróżniająca się wiedzą w zakresie funkcjonowania rynku finansowego i odpowiednich regulacji prawnych, a także posiadająca pewne doświadczenie w tym obszarze, to liczba wniosków na poziomie 228 miesięcznie ${ }^{44}$ może prowadzić do błędów, zaniedbań i zakończenia postępowania w sposób niegwarantujący pełnej ochrony praw klienta podmiotu rynku finansowego. Może o tym świadczyć niski procent zawieranych porozumień pomiędzy stronami sporu.

Mimo powyższego na podstawie przytoczonych danych statystycznych nie sposób nie zauważyć, że sektorowy podmiot ADR, jakim jest Rzecznik Finansowy, wypełnia lukę związaną z trudnościami z dochodzeniem praw konsumentów przed wymiarem sprawiedliwości ze względu na stosunkowo łatwą dostępność i niski koszt pozasądowego rozwiązania sporu przed Rzecznikiem Finansowym. Postępowanie przed Rzecznikiem Finansowym następuje w specyficznych warunkach dysproporcji pomiędzy stronami sporu.

Jak zauważał M. Lis, w przypadku dysproporcji pomiędzy stronami sporu strona słabsza ma poczucie, że musi walczyć ze sformalizowanym systemem, gdzie bez profesjonalnego pełnomocnika jest naruszane w praktyce jej prawo do obrony i sprawiedliwego osądu ${ }^{45}$. Postępowanie polubowne pozwala utrzymać relacje stron konfliktu w odpowiednich, korzystnych społecznie ramach ze względu na jego konsensualny charakter, autonomię i bezstronność, a także relatywnie niski koszt postępowania dla strony słabszej w sporze, tj. w przypadku niniejszej analizy - klienta podmiotu rynku finansowego ${ }^{46}$.

${ }^{44}$ Ibidem, s. 42.

${ }^{45}$ Cyt. za: M. Tabernacka, Mediacje - przeciwdziałanie podziałom w praktyce stosowania prawa, w: Mediacje ponad podziałami, pod red. M. Tabernackiej, Wrocław 2013, s. 23-27.

${ }^{46}$ Ibidem. 


\section{Podsumowanie}

Idea pozasądowego rozwiązywania sporów przed Rzecznikiem Finansowym jako sektorowym podmiotem ADR jest słuszna, zapewnia klientom podmiotu rynku finansowego łatwiejszy dostęp do środków ochrony prawnej, ale może okazać się nieskuteczna ze względu na brak zagwarantowania odpowiednich środków organizacyjno-prawnych, które pozwalałyby tę ochronę rzeczywiście zapewnić. W związku z powyższym pozasądowe rozwiązywanie sporów przed Rzecznikiem Finansowym może nie gwarantować konsumentom pełnej ochrony, do której mają prawo. Na podstawie danych statystycznych przytoczonych w punkcie 4 niniejszego opracowania trudno chociażby stwierdzić, że pozasądowe rozwiązywanie sporów przed Rzecznikiem Finansowym rzeczywiście charakteryzuje się szybkością postępowania.

Wziąwszy jednak pod uwagę najnowsze propozycje zmian legislacyjnych mające na celu przeniesienie kompetencji Rzecznika Finansowego w zakresie pozasądowego rozpatrywania sporów konsumenckich na Koordynatora do spraw pozasądowego rozwiązywania sporów między klientem a podmiotem rynku finansowego działającego przy Prezesie Urzędu Ochrony Konkurencji i Konsumentów oraz samoocenę działalności Rzecznika Finansowego wyrażoną w sprawozdaniu z jego działalności za rok 2019, wydaje się, że kierunek tych zmian jest słuszny. Prezes Urzędu Ochrony Konkurencji i Konsumentów jako organ posiada większe doświadczenie i uprawnienia w zakresie prowadzenia postępowań administracyjnych z udziałem podmiotów rynku finansowego ${ }^{47}$, a także więcej środków organizacyjno-prawnych, które pozwalają zapewnić ochronę konsumentów na mocy Ustawy z dnia 16 lutego 2007 r. o ochronie konkurencji i konsumentów.

Należy zauważyć, że mimo iż w praktyce sam proces nie jest bez wad, to w obecnym stanie prawnym klienci podmiotów rynku finansowego chętnie korzystają z pozasądowego rozwiązywania sporów konsumenckich przed Rzecznikiem Finansowym jako środka ochrony ich praw.

Po pierwsze, dzieje się tak dlatego, że zarówno w swoim założeniu, jak i w świadomości klientów podmiotów rynku finansowego jest to podmiot, którego celem jest działanie w zakresie ochrony ich interesów, wzbudzający w przeciętnym konsumencie zaufanie co do tego, że jego

${ }^{47}$ Ustawa z dnia 16 II 2007 r. o ochronie konkurencji i konsumentów (tekst jedn. Dz.U. 2020, poz. 1076). 
sprawa zostanie właściwie rozpatrzona. Nie bez znaczenia pozostaje tutaj również fakt, że klient już na etapie zawierania umowy jest informowany przez podmiot rynku finansowego o przysługujących mu prawach, w tym o możliwości pozasądowego rozwiązania sporu przed Rzecznikiem Finansowym, czego w innym przypadku mógłby nie być świadomy.

Po drugie, postępowanie przed Rzecznikiem Finansowym w przeciwieństwie do postępowania mediacyjnego i pojednawczego na gruncie Kodeksu postępowania cywilnego jest mniej sformalizowane i łatwiej dostępne dla konsumenta, nie tylko ze względu na poziom jego wiedzy w zakresie przysługujących mu praw. Klient podmiotu rynku finansowego jako słabsza strona w sporze może mieć poczucie, że bez profesjonalnego pełnomocnika, w tym bez odpowiednich środków finansowych, jego interesy nie będą właściwie reprezentowane, a prawa odpowiednio chronione w postępowaniu cywilnym, dlatego chętniej zwraca się do podmiotu o statusie publicznoprawnym, którego celem ustawowym jest ochrona jego praw.

\section{FORMAL ASPECTS OF OUT-OF-COURT SETTLEMENT OF DISPUTES BEFORE THE FINANCIAL OMBUDSMAN}

\section{S u m mary}

The study concerns one of the methods of amicable settlement of consumer disputes i.e. out-of-court settlement of disputes between a client and a financial market entity before the Financial Ombudsman. The Financial Ombudsman is a sectoral entity created to resolve specific disputes in the financial sector. Due to the fact that services provided by financial market entities often require special protection of consumers who are clients of financial market entities it is therefore important to ensure that the consumer has easy and effective access to legal protection measures. One such measure is out-of-court settlement of disputes before the Financial Ombudsman. Disputes regulated by civil law have been additionally regulated by public law.

Out-of-court dispute settlement before the Financial Ombudsman is indirectly an element of the implementation of the European Union legislative package concerning ADR (Alternative Dispute Resolution) aimed at providing consumers with the possibility of resolving disputes with entrepreneurs before entities offering independent, impartial, transparent, effective and quick methods of alternative disputes solving. In Poland the implementation took place in the Act of September 23, 2016 on out-of-court resolution of consumer disputes. However, out-of-court dispute settlement between a customer and a financial market entity was provided by the Polish legislator at an earlier date. It was implemented by the Act of August 5, 
2015 on complaints handling by financial market entities and on the Financial Ombudsman.

The aim of the study is to analyse the administrative and legal conditions of out-of-court dispute settlement before the Financial Ombudsman and to attempt to verify whether this process does in fact provide clients of financial market entities with quick and effective access to legal protection measures, therein protecting their interests.

Keywords: ADR - Financial Ombudsman - out-of-court settlement of consumer disputes

\section{LITERATURA}

Bogusławski A., Pozasądowe rozwiązywanie sporów z podmiotem rynku finansowego jako element ochrony konsumenta, "Finanse i Prawo Finansowe” 2016, III(1), http:// yadda.icm.edu.pl/yadda/element/bwmeta1.element.hdl_11089_17857(dostęp: 15 IV 2020).

Cauffman C., Critical Remarks on the ARD Directive, Maastricht European Private Law Institute Working Paper, no. 2016/13, https://papers.ssrn.com/sol3/papers. cfm?abstract_id=2885509 (dostęp: 15 IV 2020).

Cyman D., Zarys systemu instytucjonalnej ochrony praw konsumentów na rynku finansowym, "Gdańskie Studia Prawnicze" 2017, t. 38, https://www.ceeol.com/ search/article-detail?id=606370 (dostęp: 15 IV 2020).

Dziedzic M., Rola obowiązków informacyjnych przedsiębiorcy wobec konsumenta w sferze ustug finansowych, w: Ochrona konsumenta na polskim i międzynarodowym rynku finansowym, pod red. J. Monkiewicz, E. Rutkowskiej-Tomaszewskiej, Warszawa 2019.

Liwoch P., Rzecznik Finansowy - analiza działalności w zakresie alternatywnych metod rozstrzygania sporów, „Finanse i Prawo Finansowe” 2018, t. 4(20), http:// dspace.uni.lodz.pl/xmlui/handle/11089/26403 (dostęp: 15 IV 2020).

Loos M.B.M., Consumer ADR After Implementation of the ADR Directive: Enforcing European Consumer Rights at the Detriment of European Consumer Law, Centre for the Study of European Contract Law Working Paper, no. 2015-11, https:// papers.ssrn.com/sol3/papers.cfm?abstract_id=2685651 (dostęp: 15 IV 2020).

Rzeszowski J., Rzecznik Finansowy - "nowa-stara” ochrona konsumenta?, "Zeszyt Studencki Kół Naukowych Wydziału Prawa i Administracji UAM" 2017, nr 7, https://repozytorium.amu.edu.pl/handle/10593/18810 (dostęp: 15 IV 2020).

Tabernacka M., Mediacje - przeciwdziałanie podziałom w praktyce stosowania prawa, w: Mediacje ponad podziałami, pod red. M. Tabernackiej, Wrocław 2013.

Tabernacka M., Sporządzanie dokumentów podczas negocjacji i mediacji w sferze publicznej, w: eadem, Negocjacje i mediacje w sferze publicznej, Warszawa 2018.

Tulibacka M., Mediacja w sporach konsumenckich, w: Mediacje. Teoria i praktyka, pod red. E. Gmurzyńskiej, R. Morek, Warszawa 2018. 